\title{
REFERENCES
}

Anderson, D. H. (1949) Amer. F. Path. 25, I63.

Anderson, W. J. R., Baird, D. \& Thomson, A. M. (1958). Lancet, i, I304.

Boisselot, J. (1948). C. R. Soc. Biol., Paris, 142, 928.

Brinsmade, A. B. (1957). Beitr. path. Anat. I17, 140.

Browne, T. (1643). Religio Medici. (Quoted from 1905 edition.) London: Cassell.

Cheng, D. W. \& Thomas, B. H. (1953). Proc. Iowa Acad. Sci. 60, 290.

Chomette, G. (1955). Beitr. path. Anat. I15, 439.

Coffey, V. P. \& Jessop, W. J. E. (1958). Irish F. med. Sci. 393, 39 r.

Cohlan, S. Q. (1953). Science, 117, 535.

Edwards, J. H. (I958). Brit. F. prev. soc. Med. 12, I I 5 .

Fainstat, T. (1954). Endocrinology, 55, 502.

Fraser, F. C. \& Fainstat, T. D. (1951). Pediatrics, 8, 527.

Giroud, A. \& Boisselot, J. (1947). Arch. franc. pédiat. 4, 317.

Giroud, A. \& Lefebvres, J. (195 I). Arch. frans. pédiat. 8, 648.

Giroud, A. \& Martinet, M. (1954). C. R. Soc. Biol., Paris, 148, 1742.

Grainger, R. B., O’Dell, B. L. \& Hogan, A. G. (1954). F. Nutr. 54, 33

Hale, F. (1935). Amer. F. Ophthal. 18, 1087.

Harris, J. W. S. \& Ross, I. P. (1956). Lancet, 270, 1045.

Hoet, J. P., Brasseur, L. \& de Meyer, R. (1955). Bull. Acad. Méd. Belg. 20, r63.

Langman, J. \& van Faassen, F. (1955). Amer. f. Ophthal. 40, 65.

Millen, J. W. \& Woollam, D. H. M. (1957). Brit. med.f. ii, rg6.

Millen, J. W. \& Woollam, D. H. M. (1958a). Nature, Lond., r82, 940.

Millen, J. W. \& Woollam, D. H. M. (1958b). Nature, Lond., x81, 418.

Millen, J. W. \& Woollam, D. H. M. (1959). F. Anat. Lond., Proc, Anat. Soc. 93, 566.

Millen, J. W., Woollam, D. H. M. \& Latnming, G. E. (1953). Lancet, 265, 1234.

Nelson, M. M., Wright, H. V., Asling, C. W. \& Evans, H. M. (r955). F. Nutr. 56, 349.

Nelson, M. M., Wright, H. V., Baird, C. D. C. \& Evans, H. M. (1957). F. Nutr. 62, 395.

Record, R. G. \& McKeown, T. (I949). Brit. F. soc. Med. 3, I83.

Richardson, L. R. \& Hogan, A. G. (1946). F. Nutr. 32, 459.

Rokkones, T. (1955). Int. Z. Vitaminforsch. 26, I.

Runner, M. N. \& Miller, J. R. (1956). Anat. Rec. 124, 437.

Smithberg, M., Sanchez, H. W. \& Runner, M. N. (1956). Anat. Rec. 124, 441.

Warkany, J., Kalter, H. \& Geiger, J. F. (1957). Pediat. Clin. N. Amer. p. 983.

Warkany, J. \& Nelson, R. C. (1940). Science, 92, 383 .

Warkany, J. \& Schraffenberger, E. (1944). Proc. Soc. exp. Biol., N.Y., 57, 49.

Wilson, J. G. \& Warkany, J. (1948). Amer. F. Anat. 83, 357.

Woollam, D. H. M. \& Millen, J. W. (1957). Brit. med. F. ii, 197.

Woollam, D. H. M. \& Millen, J. W. (1958). Nature, Lond., r81, 992.

\section{Body stores in human pregnancy and lactation}

\section{By A. M. Thomson and F. E. Hytten, Obstetric Medicine Research Unit (Medical Research Council), University of Aberdeen}

It is generally believed that, in man as well as in animals, metabolism during pregnancy is strongly anabolic, storage tending to exceed the amount attributable to the growth of the product of conception and the enlargement of the organs of reproduction. The surplus is usually interpreted as a reserve for lactation, in which the trend is believed to be katabolic. But the evidence for man is scanty, and the great variation of the gain in body-weight in human pregnancy suggests that there must be many exceptions.

\section{Metabolism during pregnancy}

There was originally some controversy about the extent to which foetal growth depends on the adequacy of the diet taken by the mother, but most authorities now 
agree that within a wide range of dietetic conditions the human foetus will grow normally, if necessary at the expense of the maternal tissues. Thus, the needs of the foetus place a limit on maternal storage if the diet is inadequate for both.

The average mother gains about twice as much weight during pregnancy as can be accounted for by the growth of the product of conception and enlargement of the organs of reproduction. Table I gives mean values relating to Aberdeen primiparae who were allowed to eat to appetite during pregnancy. The mean net gain of maternal weight was $4 . \mathrm{Ig}$, of which less than $2 \mathrm{~kg}$ can be accounted for in the breasts and uterus. Little or nothing is known about the nature of the material stored and the sites of storage.

Table I. Mean distribution among different tissues of gain in weight in pregnancy of Aberdeen primiparae who were eating to appetite

$\begin{array}{lll}\text { Foetus, placenta, amniotic fluid } & 5.0 \mathrm{~kg} & \text { Lost at parturition } \\ \text { Increase of plasma and extravascular water } & 3.4 \mathrm{~kg} & \text { Quickly lost after parturition } \\ \text { Increase of maternal stores, including } & 4.1 \mathrm{~kg} & \text { Persists after parturition } \\ \text { increased weight of uterus and breasts } & & \\ \quad \text { Total gain } & 12.5 \mathrm{~kg}\end{array}$

Averages of this kind may be altered as a result of clinical policy. Pre-eclampsia, an abnormality of late pregnancy characterized by hypertension and often by oedema and proteinuria, is usually accompanied by high gains in body-weight, which many obstetricians try to prevent. Dieckmann, Turner \& Ruby (1945) went so far as to say that the total gain of weight during pregnancy should not exceed 7 or $8 \mathrm{~kg}$, and on this standard it would be almost impossible for the mother to store nutrients in her non-reproductive tissues.

Averages also conceal a wide variation. Many pregnant women gain less than half or more than twice the average amount of weight. At present, we have very little idea of the physiological and clinical significance of such variations. High gains appear to connote excessive storage of water as well as of 'solid' tissue and are accompanied by an increased incidence of pre-eclampsia, whereas low gains are associated with reduced birth weights ('Thomson \& Billewicz, 1957; Thomson, 1959).

Serial measurements of body composition during pregnancy are difficult. Most is known about changes in body water and its 'compartments', but some of the techniques used in the past are now known to be misleading. Calculations that involve the use of constants relating to the non-pregnant state, for example the intracellular water content, are also likely to be misleading; there is no doubt that the milieu intérieur, far from being constant, undergoes necessary changes during pregnancy. Much less is known about changes in the 'solid' tissues during pregnancy. Many pregnant women say that they 'put on fat', especially around the hips. Skinfold measurements may help to confirm such statements, but at present there seems to be no satisfactory way of measuring the total body fat gained or lost.

Storage can be measured also in balance studies. We will consider nitrogen metabolism only. Murlin (1917) and Mellanby (1933) believed that the nitrogen 
balance during the first half of pregnancy is negative. Though the absence of satisfactory evidence in man was admitted, they considered a negative balance to be physiological, and due to extensive proteolytic activity by the trophoblast. Vomiting in early pregnancy was interpreted as a sign rather than as a cause of katabolism. The scanty evidence now available indicates that in man retention of protein is usual in early as well as in late pregnancy. Harding ( $\left.19^{2}, 5\right)$ wondered if this might be a uniquely human characteristic.

A positive nitrogen balance is undoubtedly usual during the second half of pregnancy. Macy \& Hunscher (1934) estimated that there is an average total retention during pregnancy of more than $500 \mathrm{~g}$ nitrogen, of which about $370 \mathrm{~g}$ are stored in the maternal tissues as a reserve 'to prepare the maternal body for meeting the physiologic needs of lactation'.

Most of the balances cover short periods only, and may not be reliable. But three continuous balances from mid-pregnancy or earlier to parturition agree in showing net nitrogen storage, after allowing for losses at parturition, ranging from about $200 \mathrm{~g}$ to at least $446 \mathrm{~g}$ (Hoffström, 1910; Wilson, 1916; Hunscher, Hummell, Erickson \& Macy, 1935). If figures such as these are representative, the nitrogen must be stored as protein without much associated water; otherwise they are almost impossible to reconcile with the accepted averages for weight gain during pregnancy. It may be that nitrogen-balance experiments tend to overestimate the extent of storage, as is suggested by some studies of animals where the results have been checked by carcass analysis (Nehring, 1957).

\section{Metabolism during lactation}

We have reviewed this subject in more detail elsewhere (Hytten \& Thomson, r960).

Nitrogen balances are strongly negative for a few days after parturition, when the uterus is involuting and the maternal organism is readjusting to the non-pregnant state. The relatively few balances that have been made after the immediate puerperal phase mostly indicate retention. The reverse idea, that the balance is characteristically negative during the period of mature milk flow, seems to rest almost entirely on analogy with animals, and on one woman studied during her fourth lactation by Hunscher et al. (1935). In two previous lactations, the nitrogen balance of the same woman seems to have been positive (Hunscher, Donelson, Nims, Kenyon \& Macy, 1932-3).

We therefore doubt that nitrogen katabolism is characteristic of human lactation. The losses of protein in breast milk are relatively small, usually less than Io g/day and, if the diet is reasonably adequate, reserves should not be necessary. On the other hand, the production of milk may require the expenditure of at least 1000 $\mathrm{kcal} / \mathrm{day}$, an amount which may not readily be supplied from the current diet. Thus, the provision during pregnancy of a reserve of energy in the maternal tissues appears to have practical value. The storage of energy mainly in the form of fat rather than of protein seems probable.

If body stores are used during lactation, the mother must lose weight. Very little information is available. The few studies of metabolism during lactation in which 
changes of body-weight are given show gains as well as losses. We have compared trends in the body-weights of thirty-seven Aberdeen primiparae who lactated for at least 10 weeks and thirty-five who lactated for not more than 3 weeks. A majority in both groups lost weight, but more in the breast-feeding group, in which the average loss was also greater. The women who lost most weight suffered most from tiredness, backache and other symptoms of impaired health.

There seems to be no correlation between the amount of weight gained during pregnancy and the yield and composition of breast milk. Apparently the production of milk, like foetal growth, can if necessary proceed more or less normally at the expense of the ordinary maternal tissues. The provision of special stores during pregnancy thus seems to be more important from the point of view of the lactating mother's health and well-being than from that of milk production.

\section{Conclusions}

Obviously, more research is needed. It is certain that the balance sheet of storage and loss varies greatly. We need measurements of the amounts of materials stored or lost, and analyses of the clinical significance of different patterns. Only in this way can we decide what is 'normal' and physiological, and what indicates inefficiency or abnormality.

\section{REFERENCES}

Dieckmann, W. J., Turner, D. F. \& Ruby, B. A. (1945). Amer. F. Obstet. Gynec. 50, 701.

Harding, V. J. (r925). Physiol. Rev. 5, 279.

Hoffström, K. A. (1910). Skand. Arch. Physiol. 23, 326.

Hunscher, H. A., Donelson, E., Nims, B., Kenyon, F. \& Macy, I. G. (r932-3). F. biol. Chem. 99, 507.

Hunscher, H. A., Hummell, F. C., Erickson, B. N. \& Macy, I. G. (1935). F. Nutr. 1o, 579.

Hytten, F. E. \& Thomson, A. M. (1960). In Milk: the Mammary Gland and its Secretion. (S. K. Kon and A. T. Cowie, editors.) New York: Academic Press Inc. (In the Press.)

Macy, I. G. \& Hunscher, H. A. (1934). Amer. F. Obstet. Gynec. 27, 878.

Mellanby, E. (1933). Lancet, 245, I I31.

Murlin, J. R. (1917). Amer. Y. Obstet. Dis. Wom. 75, 91 3.

Nehring, K. (1957). Biochem. Z. 328, 549.

Thomson, A. M. (1959). Brit. F. Nutr. 13, 509.

Thomson, A. M. \& Billewicz, W. Z. (1957). Brit. med. F. i, 243.

Wilson, K. M. (I916). Johns Hopk. Hosp. Bull. 27 , I 2 r.

\section{The influence of nutrition on female fertility in some of the large domestic} animals

\section{By S. L. HignetT, Wellcome Veterinary Research Station, Frant, Sussex}

Little reliable information concerning the influence of nutrition on the fertility of larger animals exists. There have been few well-planned experiments, but many expressions of opinion based on field observations. The views put forward are often conflicting and irreconcilable with the existing circumstances, which tends to throw suspicion on those who attach importance to the influence of nutrition on the fertility of large animals. 